\title{
The influence of ICTs in vocabulary learning: an empirical study
}

\author{
Antonio R. RAigón RodrígueZ \\ $\mathrm{M}^{\mathrm{a}}$ Elena Gómez Parra \\ Universidad de Córdoba (España)
}

Recibido: 14 marzo 2005 / Versión aceptada: 15 abril 2005

ISSN: $1697-7467$

\begin{abstract}
This paper is a reflection on the influence of Information and Communication Technologies (ICTS) on acts of learning and new ways of teaching. After offering a brief review of the literature that concerns this article (Communicative Language Teaching [CLT], lexicology, ICTs), it reports on the design and outcomes of an experiment carried out in the Faculty of Education at the University of Córdoba with a group of twenty third year students studying to be English teachers. The results are revealing, as these students show learning differences in their command of the terms related to assessment before and after our intervention.
\end{abstract}

Key words: ICTs, learning, teaching, qualitative and quantitative data, assessment, questionnaire.

RESUMEN: Este trabajo supone una reflexión sobre la influencia de las Tecnologías de la Información y Comunicación (TICS) en los actos de aprendizaje y en las nuevas formas de enseñanza. Tras ofrecer una revisión teórica de la literatura en la que se apoya este artículo (Enfoque comunicativo, lexicología y TICs,), presentaremos el diseño y los resultados de un experimento llevado a cabo en la Facultad de Ciencias de la Educación de la Universidad de Córdoba con un grupo de veinte alumnos del tercer curso de Maestros de Inglés. Los resultados serán reveladores, ya que estos alumnos muestran diferencias significativas en el dominio de los términos relacionados con la evaluación antes y después de nuestra intervención.

Palabras clave: $T I C s$, aprendizaje, enseñanza, datos cualitativos y cuantitativos, cuestionario.

\section{INTRODUCTION}

This article aims to analyse, from both theoretical and practical viewpoints, the influence of $I C T s^{1}$ on new ways of learning and teaching in the twenty-first century. Our hypothesis is based on the idea that ICTs are creating a new way of learning and teaching (not only, but especially in the area of second languages). This theoretical review will be based on three

1 ICTs stands for Information and Communication Technologies. 
pillars: ICTs, lexicology and CLT. The practical analysis of our study is made up of two essential components:

a. The subjects will be third year students in the Faculty of Education (future teachers of English). They will be involved in an experiment concerning their learning of assessment terms.

b. As stated above, our study is based on a determined area of vocabulary, which, at the same time constitutes an essential item in the general curriculum of these students: assessment.

This analysis will yield results which will be analyzed in the last part of this paper.

Our hypothesis will be the following: ICTs will have a positive influence on the learning of vocabulary. To test such hypothesis, we will study the results of an experiment applied to a group of students belonging to the Faculty of Education at the University of Córdoba (Spain). So, our first step will be to analyze the teaching situation and the theoretical foundations that underlie our study.

All language teaching (LT) must be based, at least, on three foundations:

(a) The theoretical basis of teaching, which also implies the theoretical basis of learning. In this study they are the following ones: Communicative Language Teaching, Lexicology, and ICTs. This analysis can be found in section n. 2 Theoretical REVIEW.

(b) An adequate selection of linguistic contents: assessment in our experiment. We devote section $n .3$ Assessment to the analysis of the selection criteria of the terms and the establishment of the final corpus.

(c) The participants and the design of the experiment will be explained in section n. 4 THE INTERVENTION.

This study includes two further sections:

(d) A complete analysis of the data yielded by our experiment (section $n .5$ RESULTS AND ConClusions.

(e) Section n. 6 Bibliographical References.

\section{Theoretical ReView}

As previously stated, our first step must be to establish the theoretical foundations on which this article is based: (a) Communicative Language Teaching, (b) The Lexical Approach with a Cognitive basis, and (c) ICTs and Distance Learning. Let us begin at the beginning, that is, by setting out the importance of each of these for our purposes.

(a) Communicative Language Teaching. The history of methods in $\mathrm{L}^{2}$ learning and teaching has undergone different stages, and quoting Gómez and Roldán, 2004: 82, "The

2 L2 stands for Second Language. 
history of methods and approaches in language teaching is deeply influenced by their cyclical nature: each new method is born against the negative aspects and from the positive aspects of the previous one(s)."

Teachers of Applied Linguistics find it difficult to explain how and why all approaches have had such varied viewpoints regarding the teaching of a second language. In addition to this, it is also a little bit 'odd' to explain all linguistic theories and their influence on language learning and teaching, especially when teachers of English know so little about how they are met or applied in the textbooks they use for their classes. We are deeply convinced that the first question for all language teaching professionals would be: "Am I really aware of what 'teaching' means?" Needless to say, the second question following this one should be: "Do I know what 'learning' means?" By answering them, the language teacher should be quite ready to apply one or other theory to the daily practice of language teaching, thus consequently, being ready to know what is happening to his/her students when learning is taking place.

The so-called history of methods began in the nineteenth century with the Grammar Translation Method and it continues to change until the most recent approaches ${ }^{3}$. One of the most renowned of these approaches has been the Communicative Approach, whose boom can be found in the 80's. Current teachers of English still follow the $C L T^{4}$, mainly because most textbooks are based on the ideas that language must be functional and communicative (cf. Widdowson, Labov, Halliday). This approach has been quite criticized and, nowadays, there exists a tendency towards more eclectic approaches (see Ur 1996 and Beale 2002). CLT has had the objective of making the student fluent and communicative in real contexts, that is, making the student competent. The methodology applied by teachers has been quite varied in the practice of language by favouring interactive situations, students' creativity, and varied classroom practices.

This study will use the benefits of $C L T$ in the following: we want our students $\left(3^{\text {rd }}\right.$ year, Faculty of Education of the University of Córdoba) to end up being fluent in their knowledge and command of the terms concerning assessment. So, it is our goal to make them learn and use these concepts in their correct sense, in the correct contexts and with the correct purpose ${ }^{5}$.

In addition to this, most authors of primary text books still use the CLT approach, so our future professionals will have to deal with the forms and the perspective that such an approach brings into their classrooms. Assessment, thus, has proved to be an essential piece in the organisation of the general curriculum of our students: when they assess or evaluate their own students (from the Primary cycle), they will use procedures, terminology and objectives related to $C L T)$.

(b) The Lexical Approach with a Cognitive basis. Bearing in mind the pros and cons of $C L T^{6}$, we still believe it is a good beginning which, properly implemented, can be used as the starting point for our experiment. This implementation will have two main branches: Lexicology

${ }^{3}$ For a good review on the history of methods, see Richards and Rodgers (1986/2001).

4 CLT stands for Communicative Language Teaching.

${ }^{5}$ Refer to section 4 below for further information on the details of the experiment: students, corpus, etc.

${ }^{6}$ Among others: didactic proposals are not always consistent with objectives; sentence (not text) reference; breaking down of contents, etc. 
and Cognitivism. The teaching of English has been focused over the last decade on the Lexical Approach (cf. Lewis, 1994; Hamilton, 2001). Thus, most teaching professionals have included the lexis in their classes, making the students aware of the importance of learning vocabulary (as well as structures or functions). The recognition (coming out of the CLT) that speakers did not need to construct grammatically perfect sentences to be understood in the L2 has been decisive for the focus of lexis in ELT (English Language Teaching). Similarly decisive has been the idea promoted by Nattinger and DeCarrico,1992, that the lexical phrase (or chunk) could be analyzed and exploited for language teaching. Thus, syllabuses could be organized around a lexical principle with the same validity as those used before by structuralists. The emphasis is now on implementing ELT with the lexical content in a more systematic way. As mentioned before, our Lexical Approach will have a cognitive base. Cognitivism makes reference to the mental processes that the human brain activates to process information from the outside. Its application in language learning and language teaching is crucial for establishing the viewpoint from which teaching is visualized: from now on it is not only important how you teach, but also the way your students learn, what strategies they use, what decisions they make to solve their learning difficulties, etc. Its importance is irrefutable; nowadays, a curriculum is not conceivable without the cognitive contribution.

(c) ICTs and Distance Learning. The last of the foundations of our study will be ICTs and Distance Learning which have been fundamentally linked to the Lexical Approach (from a Cognitive perspective) and CLT, because they all share the use of language for the need of communication.

ICTs have contributed to the development of this approach, mainly with the benefit of a fundamental concept: self-learning without the help of a teacher (human presence), but with the only assistance of a computer. The outcome for teachers (and for teaching) is clear: some type of learning is facilitated through the use of a computer because the new software can imitate a human's mental schemata (up to a point, at the present time).

Distance learning courses are in vogue throughout the world. Quoting González, 1997: 8 , "distance learning will soon become the hottest education fad in decades". Our research does use ICTs and Distance Learning for the experiment, although a whole course design will not be needed ${ }^{7}$ for the testing of our hypothesis. Our position regarding the use of ICTs in learning/teaching contexts has a lot to do with the constructivist philosophy in which learners are seen as constructors of their own knowledge through active intervention in the learning process. Computers (among other instruments) are seen as one of the many tools which students can use. But the teacher is not a dispensable element in the general frame for learning and teaching. As pointed out before, there are three foundations for teaching/learning: the theory for teaching and learning, the selection of contents, and the techniques for doing so. We consider the human agent to be necessary in these three steps: it seems quite obvious that the teacher (or instructor, as referred to in the terminology concerning technologies) is needed to establish the theoretical frame in which teaching and learning will take place; s/ he is the agent who decides the linguistic contents applicable to each case (course, level, etc.) and, finally, but no less importantly, who chooses the techniques (also the tools) which will

\footnotetext{
${ }^{7}$ For the characteristics of the experiment design, refer to section 5 ahead.
} 
be used. According to Callejo (2001), a new relationship between the student and the teacher has been created, whose advantages can be summarised as follows ${ }^{8}$ :

- Learning will not be a memory-based activity, but rather a critical reflection.

- The relationship between the teacher and the student will not be based on discipline, but on the problem-solving objective of the learning activity.

- Time will be less important than the activity itself.

- People's main objective will be to create a community of shared knowledge.

The learner, of course, is the other necessary 'element' for this frame. S/he is the one who decides to learn, who decides which cognitive strategies are applicable and, to sum up, the agentive element in the learning frame. This picture states quite clearly our position regarding ICTs and Distance Learning: we favour its application as a help in the learning/ teaching process, but not as the only tool used by the students. The human presence and the conditions created by the agentive roles that are activated in a classroom are, from our viewpoint, necessary for the establishment of the interaction in which learning and teaching take place. Interactionist $S L A^{9}$ theories (Pica, 1996) state that interaction is decisive in the learning of a second language. Interaction, so, is defined as the 'comprehensible input' (cf. Krashen, 1985 and 1994) which allows the message to be understood, plus the 'output' (Swain, 1995) which offers the student the means for expression and negotiation of meaning.

\section{Assessment}

The importance of assessment in the learning-teaching process is undisputable. This interest has been reflected in the growing number of bibliographical references that we find nowadays. Thus, we can read in Ellis, 1998:

There has been a strong surge of interest in the goals, roles and methods of evaluation in language teaching over the last few years [...] The growing interest in evaluation has manifested itself in a concern for macroevaluation of programmes and projects. (Ellis, 1998: 217).

More specifically, within the area of second language teaching, Baxter, 1997 answers the questions why and for what purpose we evaluate:

As foreign language teachers we evaluate the student's ability in a foreign language (grammar, vocabulary, ability to listen, writing, reading, speaking, pronunciation, spelling, etc.) to compare students with each other ('proficiency test'); to see if students meet a particular standard ('placement test'); to help the students' learning and to check if the teaching programme is doing its job ('achievement test'); to check if there are any problems ('diagnostic test'). (Baxter, 1997: 2).

${ }^{8}$ Our translation: Spanish in the original.

${ }^{9}$ SLA stands for Second Language Acquisition. 
The Spanish author Miguel Ángel Santos Guerra points out: "La escuela tiene que aprender para saber y para saber enseñar, para saber a quién enseña y dónde lo hace" (Santos Guerra, 2000: 13).

This is a crucial idea if we take into account the fact that our University students will have to be constantly evaluating their teaching process. Since they will have to face this challenge, the least we can do is to provide them with the appropriate tools for it. This experiment is aimed at this goal.

\section{The INTERVENTION}

As said above, our main goal is to offer an answer to a problem found within the general curriculum of the studies of the degree of "Maestro en Lengua Extranjera (Inglés)" in the Faculty of Education of the University of Córdoba. During their academic years, these students are unable, mainly because of time factors, to acquire a minimal lexicon related to their future professional domain. This will hinder their competence as teachers of English. Moreover, the bibliography related to their own "craft" regarding assessment will be unreachable for them due to the fact that they do not possess the basic "tools". With this intervention, we will demonstrate that Distance Learning may provide an option in order to improve their access to this kind of literature.

We will prove that, by means of our interactive computational model, students will be able to acquire a high number of words in a relatively short period of time. We have chosen a specific theoretical area from the curriculum of their studies: assessment. By means of the design of different kinds of exercises, students will acquire a list of selected items, which will constitute the core of an area of knowledge and which will improve their proficiency.

The materials we have designed are accessible through the "Aula Virtual" (http:// aulavirtual.uco.es/) of the University of Córdoba, as well as with the help of a CD Rom in case either we or they need to work offline. Thus, it is highly convenient for self-study and different learning paces.

\section{a. Participants}

The chosen students belong to the third year of "Maestro de Lengua Extranjera (Inglés)". Nineteen of them have been randomly chosen and the proportion of male and female is similar to that of the total of the class ( 15 female, 4 male). The results are intended to be treated anonymously and they have been given a week to return the required feedback. For those who do not have Internet access at home, or prefer to do the exercises at the Faculty, the computer lab has been reserved for their use.

\section{b. Design of the intervention}

The first step of our experiment was, of course, to choose the software needed for the design of our exercises, Hot Potatoes ${ }^{\circledR}$. 


\section{Hot Potatoes ${ }^{\circledR}$}

Hot Potatoes suite software is a bundle made up of trademarked tools developed by the Research and Development Team of the University of Victoria. This software allows the creation of interactive activities that can be used in web environments.

Even though the exercises are created using JavaScrip, the user needs no previous knowledge of web page design. We only have to enter the information (texts, questions, answers...) and Hot Potatoes ${ }^{\circledR}$ will create a html file that can be uploaded directly to any web page. By means of the software options toolbar, we are able to modify the outcome of our work.

Hot Potatoes ${ }^{\circledR}$ has the added advantage of being freeware in its non-commercial use. The only requirement is that the exercises created must be shared, as well as the results

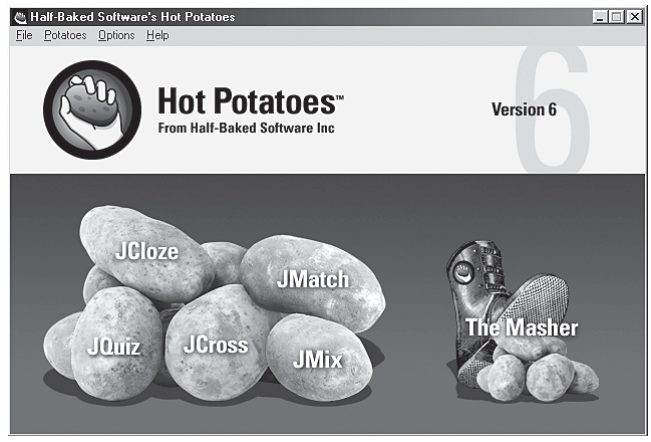
through the Internet.

As we can see in the picture, there are several types of exercises that can be easily created with Hot Potatoes:

- JCloze: it is used to design "fill-in-the-gaps" exercises.

- JQuiz: Short answers and multiple-choice questions.

- JMatch: Many options to create matching exercises.

- JCross: Automatically created crosswords.

- JMix: Jumbled sentences used mainly for students who have problems with word order.

The Masher is a completely different tool. It is intended to help you create a whole unit with several exercises. This has to be licensed and, consequently, paid for. With very little experience in webpage design, anyone can do this on his/her own for free.

All the above can be completed with texts, pictures, videos or audio. These advantages make Hot Potatoes a great tool for the creation of educational activities.

As we explained earlier, the resulting exercises are organised in the following webpage.

This is the complete list of exercises that the page contains:

1. Types of decision tests 1

2. Types of decision tests 2

3. Types of decision tests 3

4. Test, measurement and evaluation 1

5. Test, measurement and evaluation 2

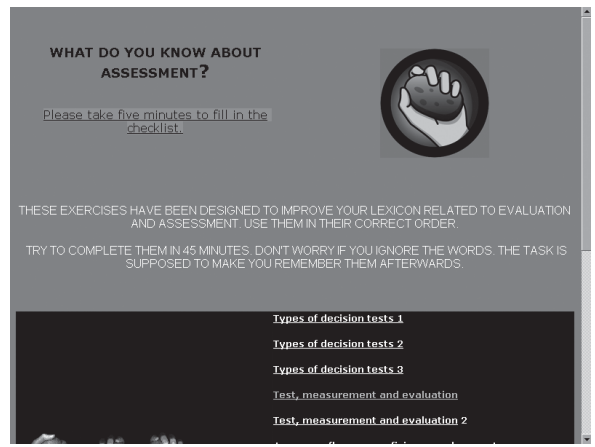


6. Accuracy, fluency, proficiency and competence

7. Collecting data techniques 1

8. Collecting data techniques 2

9. Assessment types 1

10. Real life assessment

11. Summative and formative assessment

12. Assessment types 2

Let us show an example of each of these, so that our reader can see at a glance the type of exercises our students will have to face:

Type 1: "JCloze". The exercises created with this tool are: "Types of decision tests 1, $2, \& 3$ " and "Test, measurement and evaluation 1 \& 2".

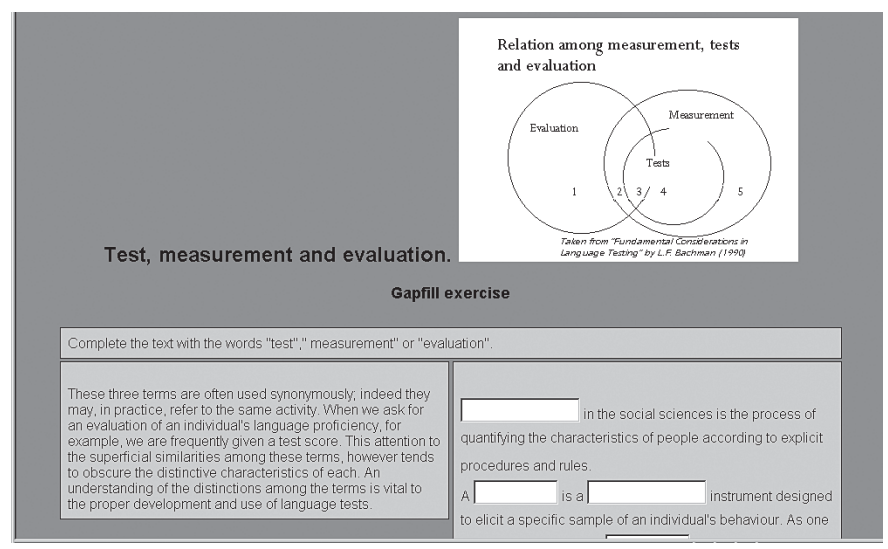

Type 2: "JQuiz". This tool has been used for the following exercises: "Real life assessment", "Summative and formative assessment"

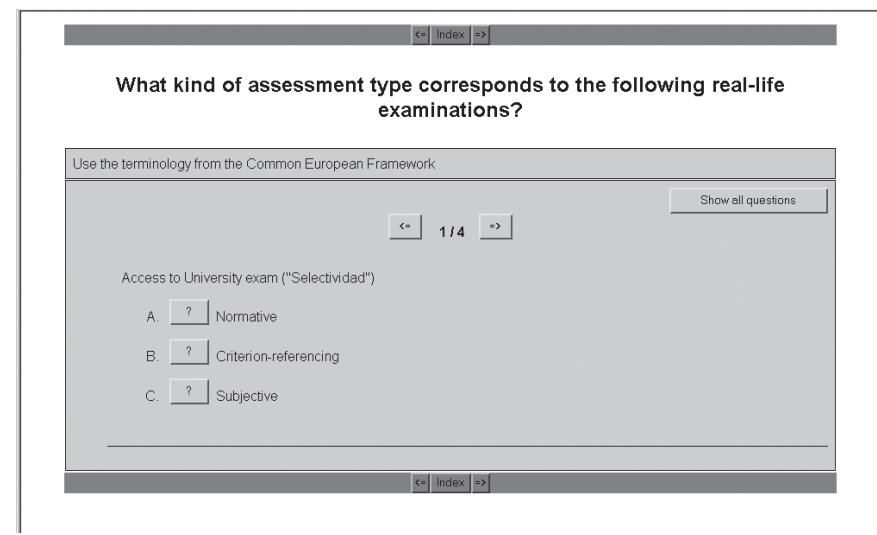


Type 3: "Match". Finally, the exercises designed with this are the following: "Accuracy, fluency, proficiency and competence", "Assessment types", "Collecting data techniques 1 \& 2", and "Assessment types 1".

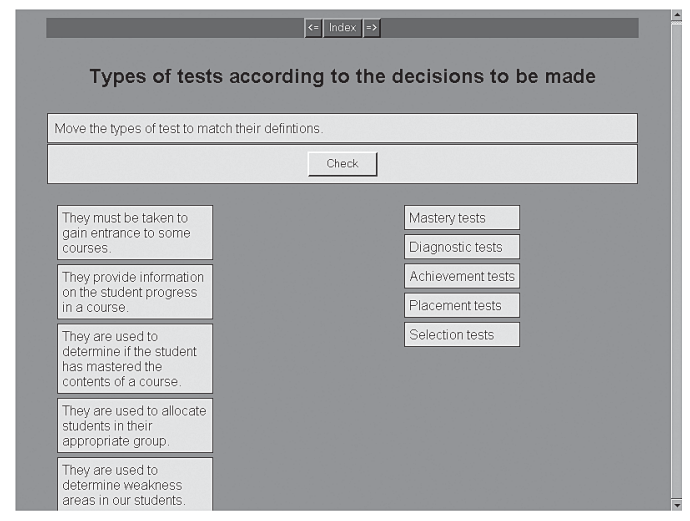

The order of the exercises and the vocabulary items have been carefully selected as we will explain later in section ii. Assessment-related corpora.

This selection and design of exercises is based on the fact that in an upper-intermediate level it is diffficult to keep pace in the amount of vocabulary learnt or acquired by an individual who is not living in an English-speaking community. This has been largely dealt with by Peter Groot:

There is not enough time to copy the natural (largely incidental) L1 word acquisition process. Incidental acquisition of the words is only possible up to a point, because, on account of their low frequency, they do not occur often enough in the L2 learning material. Acquisition of new words from authentic L2 reading texts by means of strategies such as contextual deduction is not a solution for a number of reasons. There appears to be no alternative to intentional learning of a great many new words in a relatively short period of time. The words to be learned may be presented in isolation or in context. Presentation in bilingual word lists seems an attractive shortcut because it takes less time than contextual presentation and yields excellent short term results. Long term retention, however, is often disappointing so contextual presentation seems advisable. (Groot 2000: 65).

We agree with this author regarding the need to create contextualized exercises to improve the lexical acquisition process of more specific vocabulary learning at higher levels. This seems to be the only viable alternative to using realia, which would be the ideal procedure if not for the lack of time. However, often these two alternatives are not exclusive and, thus, most of the texts that we have used are taken from relevant authors, although it might be argued that the selection and clipping of these pieces of writing is an artificial method. 


\section{ii. Assessment-related corpora}

The corpus is made up of more than fifty key concepts related to evaluation in assessment. They have been taken from both classic and new works on Language Teaching and Applied Linguistics. They have been chosen according to the following criteria:

- Key words regarding assessment.

- Terms that are frequently found in texts related to assessment, especially in recent works.

- Words considered difficult to acquire for our students.

- Words that will be useful in the future for our students and that will enable them to communicate in relation to this specific subject.

The selection was focused on the acquisition of vocabulary items that will make our students independent and "competent" in second language assessment. We intend to make them ready for future self-learning.

In this particular exercise, we used 29 interrelated items.

\section{iii. Structure of the intervention}

Firstly, the participants must fill in a questionnaire in which they self-check their knowledge regarding the assessment terms chosen for the experiment. This is what we have called the "pre-test":

Tick where appropriate

(Before using the exercises)

Figure 1: Pre-test.

\begin{tabular}{|l|l|l|l|}
\hline & $\begin{array}{c}\text { I Know this } \\
\text { word }\end{array}$ & It rings a bell & Never heard of it \\
\hline Accuracy & & & \\
\hline Achievement test & & & \\
\hline Class discussion & & & \\
\hline Competence & & & \\
\hline Continuum criterion-referencing & & & \\
\hline Criterion-referencing & & & \\
\hline Diagnostic test & & & \\
\hline Evaluation & & & \\
\hline Final assessment & & & \\
\hline Fluency & & & \\
\hline Formative & & & \\
\hline Initial & & & \\
\hline Interview & & & \\
\hline Mastery criterion-referencing & & & \\
\hline Mastery test & & & \\
\hline Measurement & & & \\
\hline Norm-referencing & & & \\
\hline Observation & & & \\
\hline Placement test & & & \\
\hline Process assessment & & & \\
\hline Proficiency & & & \\
\hline
\end{tabular}


ANTONio R. RAIGÓN RodRígueZ The influence of ICTs in vocabulary learning: an empirical study

This checklist provides us with very important information. We are made aware of the real position from which our students start.

The second obvious step is for the students to use the web page that we have created, as seen above. This intervention consists of 12 Hot Potatoes-designed exercises, which are organized following certain steps widely accepted in vocabulary acquisition: deduction, consolidation, reinforcement and production or lexical retrieval. The exact order in which the exercises are laid on the page must be followed ${ }^{10}$.

When they have finished, they are asked to fill in a very similar checklist to the one above in order to self-evaluate their own level of achievement. We include it in the following figure:

Figure 2: Post-test.

\begin{tabular}{|l|l|l|}
\hline & I Know this word & I don't know this word \\
\hline Accuracy & & \\
\hline Achievement test & & \\
\hline Class discussion & & \\
\hline Competence & & \\
\hline Continuum criterion-referencing & & \\
\hline Criterion-referencing & & \\
\hline Diagnostic test & & \\
\hline Evaluation & & \\
\hline Final assessment & & \\
\hline Fluency & & \\
\hline Formative & & \\
\hline Initial & & \\
\hline Interview & & \\
\hline Mastery criterion-referencing & & \\
\hline Mastery test & & \\
\hline Measurement & & \\
\hline Norm-referencing & & \\
\hline Observation & & \\
\hline Placement test & & \\
\hline Process assessment & & \\
\hline Proficiency & & \\
\hline Selection test & & \\
\hline Self-as ses ment & & \\
\hline Sociometry & & \\
\hline Student work & & \\
\hline Subjective & & \\
\hline Summative & & \\
\hline Survey & & \\
\hline Test & & \\
\hline
\end{tabular}

${ }^{10}$ These exercises and their types are laid in the list of the section $i$. Hot Potatoes ${ }^{\circledR}$. 
Finally, we will get more feedback from the following questionnaire with both quantitative and qualitative data. This is widely recognised as an extremely useful tool in educational research (Madrid y Pérez, 2004: 130). This is the final questionnaire they are asked to fill in:

Por favor, completa este cuestionario con tus impresiones personales sobre el programa que acabas de utilizar. El cuestionario es totalmente anónimo, por lo que te pedimos que seas lo más sincero posible. Los números corresponden a:

1: Muy en desacuerdo

2: En desacuerdo

3: Indeciso

4: De acuerdo

5: Muy de acuerdo

Figure 3. Personal questionnaire.

\begin{tabular}{|c|c|c|c|c|c|}
\hline \multirow{2}{*}{ Tenía conocimientos previos de los términos que hemos tratado. } & 1 & 2 & 3 & 4 & 5 \\
\hline & & & & & \\
\hline Los ejercicios me han servido para mejorar mis conocimientos. & & & & & \\
\hline Sería capaz de usar los términos aprendidos en contextos reales. & & & & & \\
\hline $\begin{array}{l}\text { Me parece que este sistema puede ser positivo para el aprendizaje } \\
\text { de vocabulario. }\end{array}$ & & & & & \\
\hline He conseguido por lo general buenas puntuaciones en los ejercicios. & & & & & \\
\hline $\begin{array}{l}\text { Es posible aprender vocabulario con la única ayuda de este progra- } \\
\text { ma. }\end{array}$ & & & & & \\
\hline Valoro positivamente la experiencia. & & & & & \\
\hline Mi nivel de inglés es bueno. & & & & & \\
\hline $\begin{array}{l}\text { Mi nivel de inglés no me ha permitido realizar los ejercicios de la } \\
\text { manera apropiada. }\end{array}$ & & & & & \\
\hline Tengo conocimientos informáticos. & & & & & \\
\hline El uso del programa interactivo es bastante fácil. & & & & & \\
\hline El tiempo de realización es el necesario. & & & & & \\
\hline Es necesaria la participación de un tutor. & & & & & \\
\hline
\end{tabular}

\begin{tabular}{|l|l|}
\hline ¿Qué ejercicio te ha sido más provechoso? & \\
\hline ¿Cuál te ha resultado menos provechoso? & \\
\hline ¿Qué ejercicio no has entendido? & \\
\hline Observaciones y otros comentarios. & \\
& \\
\hline
\end{tabular}


For the quantitative part of the survey, we have used a Likert scale in order to obtain students' opinions, perceptions and attitudes towards interactive learning and the use of computers, as well as their particular views on this experiment. On the other hand, we have added some open-ended questions to give students the opportunity to express their opinions more freely and get some qualitative information to complete the conclusions.

In addition, and with the intention of establishing a more "objective" kind of results, our students are asked to fill in a multiple-choice test in which there are multiple-choice questions related to the contents that they have used on the Webpage. We will evaluate these results and the conclusions are offered in the next section.

All the above-mentioned input has been used to determine the impact and effectiveness of our experiment.

\section{Results ANd Conclusions}

The analysis of the information provided by all our students will yield conclusions about the use of ICTs in the learning and teaching of the $21^{\text {st }}$ Century. Let us first establish the main data in two tables, which will show the answers that our students provided. We will split this analysis into two parts: quantitative and qualitative data.

\section{a. Quantitative data}

Figure 4. Pre-test results.

\begin{tabular}{|c|c|c|c|}
\hline & I Know this word & It rings a bell & Never heard of it \\
\hline 1 & 16 & 3 & 10 \\
\hline 2 & 19 & 5 & 5 \\
\hline 3 & 17 & 5 & 7 \\
\hline 4 & 20 & 1 & 8 \\
\hline 5 & 14 & 8 & 7 \\
\hline 6 & 17 & 4 & 8 \\
\hline 7 & 22 & 5 & 2 \\
\hline 8 & 12 & 6 & 11 \\
\hline 9 & 23 & 3 & 3 \\
\hline 10 & 9 & 10 & 10 \\
\hline 11 & 10 & 7 & 12 \\
\hline 12 & 10 & 6 & 13 \\
\hline 13 & 20 & 5 & 4 \\
\hline 14 & 22 & 2 & 5 \\
\hline 15 & 20 & 4 & 5 \\
\hline 16 & 20 & 3 & 6 \\
\hline 17 & 12 & 8 & 9 \\
\hline 18 & 16 & 3 & 10 \\
\hline 19 & 13 & 4 & 12 \\
\hline & & & \\
\hline
\end{tabular}


This table provided us with the following data:

The number in the first column indicates the number given to the student who answered (anonymously, of course). Then, we calculated the number of words s/he knew before the experiment (second column), the number of words s/he was not very sure about (third column), and finally, the number of words s/he did not know at all (fourth column).

A summary of all this can be found in the following chart:

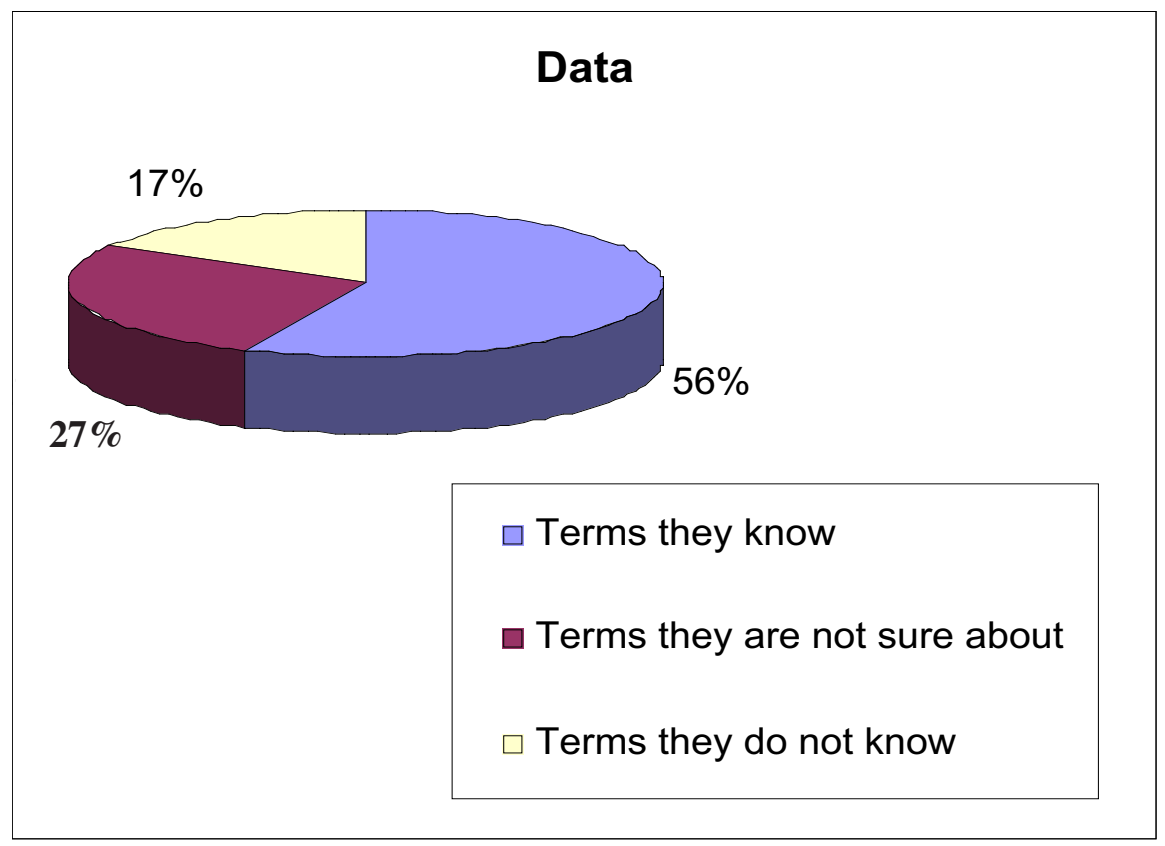


ANTONIO R. RAIGÓN RODRígueZ The influence of ICTs in vocabulary learning: an empirical study

The second table showed us these results:

Figure 5. Post-test results.

\begin{tabular}{|c|c|c|c|}
\hline & I Know this word & I don't know this word & DIFFERENCE \\
\hline 1 & 25 & 4 & 9 \\
\hline 2 & 26 & 3 & 7 \\
\hline 3 & 24 & 5 & 7 \\
\hline 4 & 26 & 3 & 6 \\
\hline 5 & 21 & 8 & 7 \\
\hline 6 & 27 & 2 & 10 \\
\hline 7 & 27 & 2 & 5 \\
\hline 8 & 27 & 2 & 15 \\
\hline 9 & 28 & 1 & 16 \\
\hline 10 & 22 & 7 & 5 \\
\hline 11 & 19 & 10 & 9 \\
\hline 12 & 23 & 6 & 13 \\
\hline 13 & 25 & 4 & 13 \\
\hline 14 & 27 & 2 & 9 \\
\hline 15 & 29 & 0 & 6 \\
\hline 16 & 26 & 3 & 12 \\
\hline 17 & 24 & 5 & 6 \\
\hline 18 & 29 & 0 & \\
\hline 19 & 20 & 9 & 9 \\
\hline
\end{tabular}

As we can see, each student (column 1) stated at the end of the experiment the number of words s/he finally knew (column 2) and the words s/he did not know (column 3$)^{11}$. The last column shows the difference between the words the students knew before the experiment, and after it.

If we carry out a simple addition of the figures that the last column contains, we can see that the nineteen students have learnt a total of 173 words (that makes an average of 9.1 words per student).

11 The category "it rings a bell" has been eliminated from this table because, after the exercises, it remained pointless. 
These results are summarized in the following chart:

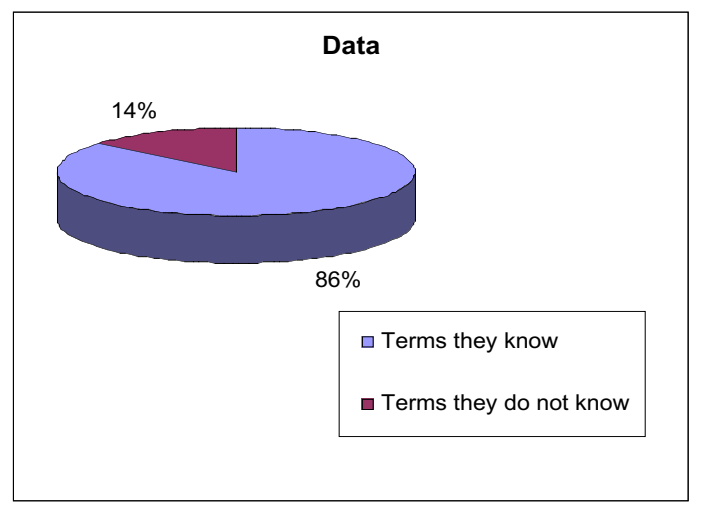

These are the data regarding the "Evaluation Test" applied to our students:

15 students scored 9 or more right answers (out of 10 questions).

2 students scored 7 or more right answers to the questions.

1 student scored 5 or more right answers to the questions.

1 student scored less than 5 right answers to the questions.

The following chart summarizes these results:

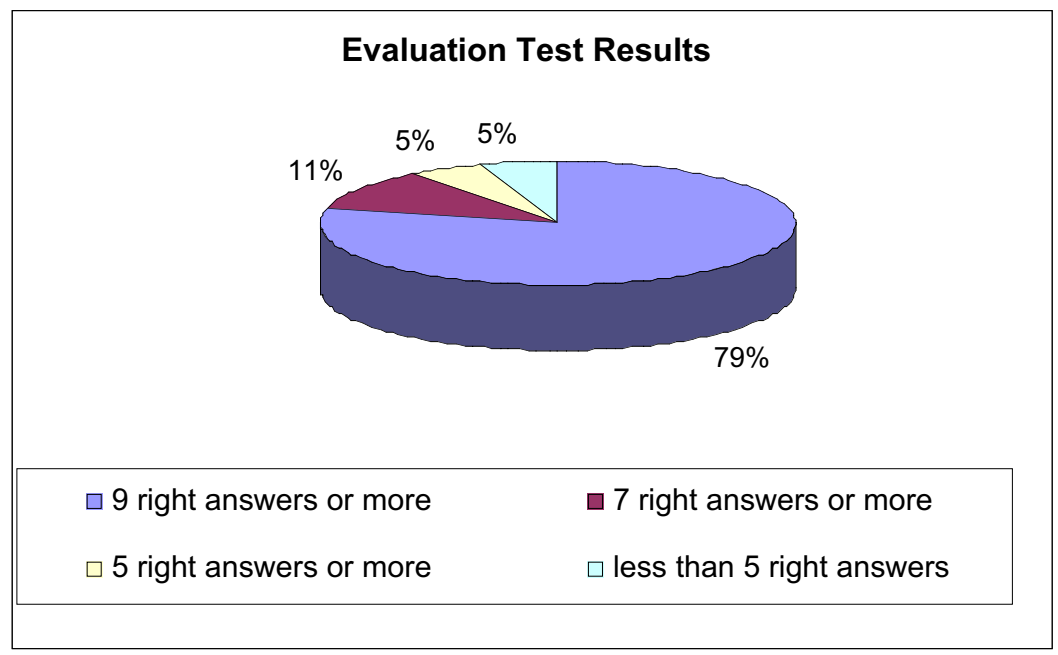


Antonio R. RAIGÓN RodRígueZ The influence of ICTs in vocabulary learning: an empirical study

Our main conclusions drawn from all the data are the following:

a. Students show quite a good command of the terms before the experiment (although not as good as one would hope). In spite of this, the results after the experiment are much better. Students improve their command of assessment terms after having worked with our tools. Without exception, all of them have claimed to know more terms at the end of the experiment than before they began.

b. They all worked under the best conditions of time, pace and (even) topic selection. Distance learning (and this tool in particular) promotes self-learning at their own speed (not all students needed a week for the experiment - some of them sent their results in just one day), with a chosen environment (at home, at the Faculty, alone, with friends, etc.) and even though we 'imposed' a rigid order in the exercises, it was quite easy just to skip over those that they already knew or to choose to alter the order.

c. The overall results of the tests applied to our students are quite good, taking into account the fact that most of them ended up the experiment with an objectively tested good knowledge of assessment terms (79\% of them provided the correct answer to almost all the questions of our test).

\section{b. Qualitative data}

The qualitative data of this experiment will be drawn from the Personal Questionnaire that our students have filled in. The next table show such data in figures, as well all the commentaries they have provided to the final questions:

Por favor completa este cuestionario con tus impresiones personales sobre el programa que acabas de utilizar. El cuestionario es totalmente anónimo, por lo que te pedimos que seas lo más sincero posible. Los números corresponden a: 
1: Muy en desacuerdo

2: En desacuerdo

3: Indeciso

4: De acuerdo

5: Muy de acuerdo

\begin{tabular}{|l|c|c|c|c|c|}
\hline & $\mathbf{1}$ & $\mathbf{2}$ & $\mathbf{3}$ & $\mathbf{4}$ & $\mathbf{5}$ \\
\hline $\begin{array}{l}\text { Tenía conocimientos previos de los términos que hemos } \\
\text { tratado. }\end{array}$ & 1 & 3 & 4 & 11 & 0 \\
\hline $\begin{array}{l}\text { Los ejercicios me han servido para mejorar mis } \\
\text { conocimientos. }\end{array}$ & 0 & 0 & 0 & 8 & 11 \\
\hline $\begin{array}{l}\text { Sería capaz de usar los términos aprendidos en contextos } \\
\text { reales. }\end{array}$ & 0 & 0 & 9 & 10 & 0 \\
\hline $\begin{array}{l}\text { Me parece que este sistema puede ser positivo para el } \\
\text { aprendizaje de vocabulario. }\end{array}$ & 0 & 1 & 0 & 4 & 14 \\
\hline $\begin{array}{l}\text { He conseguido por lo general buenas puntuaciones en los } \\
\text { ejercicios. }\end{array}$ & 0 & 1 & 4 & 12 & 2 \\
\hline $\begin{array}{l}\text { Es posible aprender vocabulario con la única ayuda de este } \\
\text { programa. }\end{array}$ & 1 & 3 & 7 & 7 & 1 \\
\hline Valoro positivamente la experiencia. & 0 & 0 & 0 & 8 & 11 \\
\hline Mi nivel de inglés es bueno. & 0 & 0 & 4 & 10 & 5 \\
\hline $\begin{array}{l}\text { Mi nivel de inglés no me ha permitido realizar los } \\
\text { ejercicios de la manera apropiada. }\end{array}$ & 8 & 7 & 1 & 3 & 0 \\
\hline Tengo conocimientos informáticos. & 2 & 1 & 3 & 5 & 8 \\
\hline El uso del programa interactivo es bastante fácil. & 0 & 0 & 2 & 5 & 12 \\
\hline El tiempo de realización es el necesario. & 0 & 3 & 3 & 7 & 6 \\
\hline Es necesaria la participación de un tutor. & 4 & 6 & 6 & 3 & 0 \\
\hline
\end{tabular}

\begin{tabular}{|l|l|}
\hline $\begin{array}{l}\text { ¿Qué ejercicio te ha } \\
\text { sido más } \\
\text { provechoso? }\end{array}$ & $\begin{array}{l}\text { El último / Types of tests according to the decisions to be made / } \\
\text { Todos me han sido muy útiles, aunque quizá los más útiles hayan } \\
\text { sido Types of decision tests and assessment por mi desconocimiento } \\
\text { del vocabulario / Real life assessment / Unir cada término con su } \\
\text { definición / Collecting data techniques / Los primeros me han } \\
\text { resultado más fáciles / Los de unir, por ejemplo; types of decision } \\
\text { tests 3; Test, measurement, and evaluation. Son más entretenidos y } \\
\text { amenos / En general, todos / Real life assessment / Types of decision } \\
\text { tests 1 / Es que no sé cuál elegir, así que el conjunto / El último / El } \\
\text { último / Types of decision / Types of decision and Test, } \\
\text { measurement, and evaluation. }\end{array}$ \\
\hline
\end{tabular}




\begin{tabular}{|c|c|}
\hline $\begin{array}{l}\text { ¿Cuál te ha } \\
\text { resultado menos } \\
\text { provechoso? }\end{array}$ & $\begin{array}{l}\text { Ninguno / Types of tests according to the decisions to be made } 2 \text { / } \\
\text { Los de True-False / Creo que todos han sido muy provechosos, } \\
\text { pero debo decir que el ejercicio Test, measurement, and evaluation } \\
\text { no deja muy clara la diferencia entre los términos / Tupes of } \\
\text { decision test } 1 \text { / Completar huecos / Types of decision test } 2 \text { / El } \\
\text { último me ha parecido más difícil / Assessment types porque es el } \\
\text { que me ha costado más trabajo adivinar / Uno de los tests acerca de } \\
\text { bajar junto a concepto su significado / Los que hay que rellenar con } \\
\text { huecos / Test, measurement, and evaluation / Pues ninguno, cada } \\
\text { uno tiene algo diferente / Ninguno / Ninguno / Test, measurement, } \\
\text { and evaluation / Assessment types. }\end{array}$ \\
\hline $\begin{array}{l}\text { ¿Qué ejercicio no } \\
\text { has entendido? }\end{array}$ & $\begin{array}{l}\text { Ninguno / Ninguno / Ninguno / Ninguno / Entendido todos los } \\
\text { ejercicios / Ninguno / Por lo general, he entendido todos / Todos se } \\
\text { entienden bien / Assessment types / Idem (Uno de los tests acerca de } \\
\text { bajar ...) / Ninguno, todos se entienden bien / Ninguno / Ninguno / } \\
\text { Ninguno / Todos estaban definidos con claridad. }\end{array}$ \\
\hline $\begin{array}{l}\text { Observaciones y } \\
\text { otros comentarios }\end{array}$ & $\begin{array}{l}\text { Creo que esta técnica es buena para aprender vocabulario / Me ha } \\
\text { gustado hacer esta actividad porque he aprendido palabras que } \\
\text { desconocía, y pienso que me van a ser de utilidad para mi } \\
\text { vocabulario / Todo está bastante bien, incluso las correcciones } \\
\text { ortográficas que te hace el programa, aunque no debería restar } \\
\text { puntuación por no escribir la letra inicial en mayúscula. Es sencillo } \\
\text { de utilizar y los ejercicios se entienden bien / Demasiado teóricos, } \\
\text { poca aplicación a la vida cotidiana / Creo que algunos ejercicios te } \\
\text { cuesta más entenderlos porque no hay nada antes que te hable sobre } \\
\text { ello. Por ejemplo, para mí el ejercicio más difícil ha sido } \\
\text { Assessment types porque son conceptos que la mayoría no había } \\
\text { visto nunca, y me ha resultado complicado acertar / Me gusta todo / } \\
\text { En el ejercicio Collecting data techniques } 2 \text { "Observation" está en } \\
\text { mayúsculas y si le pones minúsculas te da un error en esa palabra / } \\
\text { Hay algunos ejercicios que me ha costado más trabajo realizarlos } \\
\text { porque no tenía conocimientos previos acerca de algunos conceptos } \\
\text { / Nos proporciona las bases que hay que tener en cuenta como toma } \\
\text { de contacto ante la enseñanza de las lenguas. }\end{array}$ \\
\hline
\end{tabular}

We consider the data of the first table quite positive, and this is the summary of their conclusions:

a. Most of them had previous knowledge about assessment (11 students scored more than 4).

b. All of them state that they have improved their knowledge about the topic (19 students scored more of 4).

c. Half of them think they can use the terms in real contexts (10 students scored more than 4).

d. Most of them consider the use of the programme as positive for vocabulary learning (18 scored more than 4). 
e. Most of them got good results in the exercises (14 students scored more than 4).

f. Most of them think that this programme is not enough for vocabulary learning (14 students scored 3 or less).

g. All of them consider the experience as positive (19 students scored more than 4).

h. Almost all of them think their level of English is good (15 students scored more than 4).

i. Almost all of them think their level of English has been enough for this exercise (16 students scored 3 or less).

j. Almost all of them had previous computer knowledge (13 students scored more than 4).

$\mathrm{k}$. Almost all of them think that the programme is easy to be used (17 students scored more than 4).

1. Almost all of them think they had time enough for the exercise (13 students scored more than 4).

$\mathrm{m}$. Almost all of them think that a tutor is not necessary for the experiment (16 scored 3 or less).

Finally, the qualitative data shown in the second table tell us that the great majority of them consider the experiment as positive, in spite of the fact that they had their difficulties and their dislikes we can say that, generally speaking, the experience has been considered as very positive by them.

To end up, we must say that, though ICTs are not the panacea for the learning process, we consider that this experiment has demonstrated that, correctly applied, with a proper guidance and, above all, with the moderation that the context demands, they are a good instrument to be used by the teacher (and, very especially, by the language teacher).

\section{Bibliographical References}

Bachman, L. F. (1990). Fundamental considerations in language testing. Oxford: Oxford University Press.

Baxter, A. (1997). Evaluating your students. London: Richmond Publishing.

Beale, J. (2002). "Is communicative language teaching a thing of the past?", in Babel, 37, 1: 1216.

Callejo J. (2001). "Transformaciones en la comunicación entre institución y alumno con la introducción de la tutoría telemática en la enseñanza a distancia", in http://virtualdb.uned.es

Ellis, R. (1998). "The evaluation of communicative tasks", in Tomlinson, B. Material development in language teaching. Cambridge: Cambridge University Press, 217-238.

Gómez Parra, M.E. y Roldán Tapia, A. (2004). "Language Learning and Acquisition. Theories and Methods of Teaching and Learning" in D. Madrid y N. McLaren (eds.), TEFL in Primary Education. Granada: Editorial Universidad de Granada, 73-101.

González, J. M. (1997). "Technology in education: Time to face the monster", in IDRA Newsletter, 24, 5: 8-9.

Groot, P. (2000). "Computer assisted second language vocabulary adquisition", in Language Learning and Technology, 4: 60-81. 
ANTONio R. RAIGÓN RodRíGueZ The influence of ICTs in vocabulary learning: an empirical study

Hamilton N. (2001). 'Weaving Some Lexical Threads' in IH Journal, 10: 13-15.

Krashen, S. (1985). The Input Hypothesis. Beverly Hills, CA: Laredo Publishing Company.

Krashen, S. (1994). "The input hypothesis and its rivals", in N. Ellis (ed.) Implicit and explicit learning of languages. London: Academic Press, 45-77.

Lewis, M. (1993). The lexical approach: The state of ELT and the way forward. Hove, England: Language Teaching Publications.

Nattinger, J.R. and DeCarrico, J.S. (1992). Lexical Phrases and Language Teaching. Oxford: Oxford University Press.

Madrid, D. y Pérez, M.L. (2004). "Teacher and student preferences of native and non-native foreign language teachers", in Porta Linguarum, 2, 125-138.

Pica, T. (1996). "Second language learning through interaction: Multiple perspectives", in Working Papers in Educational Linguistics, 12, 1: 1-22.

Richards, J.C. y Rodgers, T. (1986/2001). Approaches and Methods in Language Teaching. Cambridge: Cambridge University Press.

Santos Guerra, M. A. (2000). La Escuela que Aprende. Madrid: Morata.

Swain, M. (1995). "Three functions of output in second language learning", in. G. Cook and G. Seidhofer (eds.), Principles and practices in applied linguistics: Studies in honor of H. G. Widdowson. Oxford: Oxford University Press, 125-144.

Ur, P. (1996). "The communicative approach revisited", in GRETA, Revista para Profesores de Inglés, 4, 2: 5-7. 